\title{
Comparative Assessment of the Proximate, Mineral Composition and Mineral Safety Index of Peel, Pulp and Seeds of Cucumber (Cucumis sativus)
}

\author{
Oluwagbenle Henry Niyi, Adesina Adeolu Jonathan*, Aremu Olawale Ibukun \\ Chemistry Department (Analytical Chemistry Unit), Faculty of Science, Ekiti State University, Ado-Ekiti, Nigeria \\ Email: httphenryo@yahoo.com, *a deolu.adesina@eksu.edu.ng, haremuw alexy7@gmail.com
}

How to cite this paper: Niyi, O.H., Jonathan, A.A. and Ibukun, A.O. (2019) Comparative Assessment of the Proximate, Mineral Composition and Mineral Safety Index of Peel, Pulp and Seeds of Cucumber (Cucumis sativus). Open Journal of Applied Sciences, 9, 691-701.

https://doi.org/10.4236/ojapps.2019.99056

Received: July 1, 2019

Accepted: September 17, 2019

Published: September 20, 2019

Copyright $\odot 2019$ by author(s) and Scientific Research Publishing Inc. This work is licensed under the Creative Commons Attribution International License (CC BY 4.0).

http://creativecommons.org/licenses/by/4.0/

\begin{abstract}
Cucumber (Cucumis sativus) is a creeping vine that bears cylindrical fruits. It belongs to the gourd family cucurbitacea. It is popularly consumed in all parts of Nigeria. The comparative assessment of proximate, mineral composition and mineral safety index (MSI) of cucumber (peel, pulp and seeds) was determined using standard analytical methods (Association of Official Analytical Chemists) for proximate, minerals composition and mineral safety index. Results showed protein content of $(15.9$ - 26.5) g/100 g, Carbohydrates (33.7 - 52.7) g/100 g, crude fat $(0.13$ - 1.44) g/100 g, moisture (12.3 - 21.7) $\mathrm{g} / 100 \mathrm{~g}$ and ash $(7.85$ - 11.6) g/100 g respectively. The calorific values were 1077,1171 and $1296 \mathrm{~kJ} / 100 \mathrm{~g}$ for peel, pulp and seed respectively. Considerable levels of essential and trace elements were observed in the samples. The $\mathrm{Na} / \mathrm{K}$ ratio $(0.25-0.36)$ was close to 0.6 , which does not promote high blood pressure in man. The $\mathrm{Ca} / \mathrm{Mg}$ values obtained were less than the recommended value of 1.0. The milliequivalent ratios of $[\mathrm{K} /(\mathrm{Ca}+\mathrm{Mg})](3.91-4.48)$ were comparably higher than the recommended value of 2.2 which means the sample would promote hypomagnesaemia in man. The mineral safety indexes of $\mathrm{Fe}, \mathrm{Na}, \mathrm{Ca}, \mathrm{Zn}, \mathrm{Cu}$ and $\mathrm{Mg}$ of the samples (peel, pulp and seeds) indicate no overloading in the body if consumed. The results showed that all the parts of Cucumis sativus are good potentials of nutrients for human consumption.
\end{abstract}

\section{Keywords}

Cucumber, Proximate, Minerals, Mineral Safety Index

\section{Introduction}

Cucumber (Cucumis sativus) is a creeping vine that bears cylindrical fruits that 
originated in Southern Asia, but a large number of cultivars have been developed and are grown worldwide. It is widely cultivated and consumed in Nigeria. $\mathrm{Cu}$ cumber (Cucumis sativus L.) is an important vegetable and one of the most popular members of the Cucurbitaceae family [1]. It is thought to be one of the oldest vegetables cultivated by man with historical records dating back 5000 years [2]. The crop is the fourth most important vegetable after tomato, cabbage and onion in Asia [3], the second most important vegetable crop after tomato in Western Europe [4]. In tropical Africa, its place has not been ranked because of limited use. The increase in human population and reports of large numbers of under-nourished or starving people, especially in the developing countries, has made the need for food production a major worldwide issue of concern [5].

Cucumber requires a warm climate. In cool, temperate countries it is grown in greenhouses; only during hot summers can it be grown in the open. The optimum temperature for growth is about $30^{\circ} \mathrm{C}$ and the optimum night temperature $18^{\circ} \mathrm{C}-21^{\circ} \mathrm{C}$; the minimum temperature for good development is $15^{\circ} \mathrm{C}$. High light intensity is needed for optimum yields. Cucumber needs a fair amount of water but it cannot stand water logging. Low relative humidity results in high plant evaporation due to the large leaf area, and sufficient irrigation is then very important. High relative humidity facilitates the occurrence of downy mildew. In tropical Africa elevations up to $2000 \mathrm{~m}$ appear to be suitable for cucumber cultivation. In Nigeria, cucumbers are grown majorly in the North particularly Jos; due to the climatic requirements.

Cucumber can grow anywhere giving the right production method and management of the environmental factor [5]. However, in Nigeria with moderate rainfall, it's now grown in the southern part with favourable yield compared with that grown in Jos. It is interesting to note that the duration of growth to harvest of cucumber is short.

Cucumbers contain 90 - 95 percent water and have limited nutritional value compared to other vegetables because of this. In one serving of cucumbers there are about 45 calories along with the daily recommended intake; $6 \%$ of Vitamin A and Vitamin B6, and 14\% Vitamin C [6]. The cucumber can aid in alleviating irritation and sunburn similarly to the aloe plant by applying the sliced cucumbers to the affected area. The slices can also reduce puffiness under the eyes (also known as "bags" under the eyes) since it has anti-inflammatory properties and stimulates hair growth. Being rich in vitamin A, B1, B6, C, \& D, Magnesium, Folate, Calcium, and Potassium, cucumbers contain a good source of silica that allows the connective tissue to be strengthened while promoting healthy joints [7]. Cucumbers contain three lignans: lariciresinol, pinoresinol, and secoisolariciresinol, all of which have traits of reducing the risk of developing several cancers such as breast cancer, ovarian cancer, uterine cancer and prostate cancer [8]. Therefore, it is in the interest of this research to look at the various chemical and nutritional compositions (proximate, mineral compositions and mineral safety index) of the anatomical parts (peel, pulp and seeds) of cucumber fruits as this will enhance its general food technological/industrial applications. 


\section{Materials and Methods}

\subsection{Sample Collection and Preparation}

Cucumis sativus (Cucumber) used for this work was obtained from Sasha market in Ado-Ekiti, Ekiti State Nigeria. The cucumber samples were authenticated at the Plant Science and Biotechnology Department of Ekiti State University for screening. After the screening the samples were separated into three parts: peel, pulp and seed. The samples were then air-dried to constant weight. Each of these parts was milled into fine powder forms, kept in an airtight container and stored in refrigerator prior to analysis.

\subsection{Proximate Composition Analysis}

The micro-Kjeldahl method [9] was followed to determine the crude protein. The crude fat was extracted with chloroform/methanol $(2: 1 \mathrm{v} / \mathrm{v})$ mixture using Soxhlet extraction apparatus. Moisture, ash and crude fibre determination followed AOAC [10] methods whilst carbohydrate was determined by difference. The calorific values in kilo Joule $(\mathrm{kJ})$ were calculated by multiplying the crude fat, protein and carbohydrate by Atwater factors of (kJ) 37, 17 and 17 respectively. Determinations were in duplicate.

\subsection{Mineral Composition Analysis}

The minerals were analysed by first dry ashing the samples at $550^{\circ} \mathrm{C}$ in muffle furnance. The filtered solutions were used to determine $\mathrm{Na}, \mathrm{K}, \mathrm{Mg}, \mathrm{Ca}, \mathrm{Fe}, \mathrm{Cu}$, $\mathrm{Co}, \mathrm{Mn}, \mathrm{Zn}, \mathrm{Pb}, \mathrm{Se}, \mathrm{Cd}$ and $\mathrm{Ni}$ by means of atomic absorption spectrophotometer (Buck Scientific Model -200A/210, Norwalk, Connecticut 06855) and phosphorus was determined colorimetrically by Spectronic 20 (Gallenkamp, UK) using the phosphovanado molybdate method [10]. All chemicals used were of British Drug House (BDH, London, UK) analytical grade. The detection limits for the metals in aqueous solutions had been determined previously using the methods of Varian Techtron. The optimal analytical range was $0.1-0.5$ absorbance units with coefficients of variation from $0.9 \%-2.21 \%$.

1) Estimation of percentage energy contribution: The proportions of energy contribution from fat, protein and carbohydrate to total energy were calculated for each nutrient type. Values were reported in both $\mathrm{kJ} 100 \cdot \mathrm{g}^{-1}$ and percent. Also calculated was the utilization of energy due to protein (UEDP \%) in the samples.

2) Estimation of mineral ratios: Ratios of $\mathrm{K} / \mathrm{Na}, \mathrm{Na} / \mathrm{K}, \mathrm{Ca} / \mathrm{P}$ and $[\mathrm{K} /(\mathrm{Ca}+$ $\mathrm{Mg}$ )] were all calculated.

3) Minerals safety index: The minerals safety index $(M S I)$ were calculated [11] for minerals that have relevant standards for such determination. For the present work, $M S I$ for these minerals was calculated: $\mathrm{Fe}, \mathrm{Ca}, \mathrm{P}, \mathrm{Mg}, \mathrm{Zn}, \mathrm{Cu}, \mathrm{Se}$ and $\mathrm{Na}$ using the formula:

$$
\text { Calculated } M S I=\frac{M S I X \text { research data result }}{R A I}
$$

where $M S I=$ mineral safety index from the Table (standard); $R A I=$ recom- 
mended adult intake.

\subsection{Statistical Analysis}

The analysis was carried out in duplicate and the mean values taken as results. Data from the results were subjected to statistical analysis of chi-Square $\left(\chi^{2}\right)$. The $\chi^{2}$ values were compared with the critical Table value to see if significant differences existed among the sample results at $p>0.05$ [12]. Other descriptive statistics done were the determination of mean, standard deviation and coefficient of variation percent (CV \%) [12].

\section{Results and Discussion}

\subsection{Proximate Composition}

Results of the proximate composition analysis of cucumber parts (peel, pulp and seed) were presented in Table 1 . The ash content is an indication of the concentration of minerals or inorganic component of the sample. These minerals act as inorganic co-factors in metabolic processes. Therefore if there is little or insufficient quantity of these inorganic co-factors, it could result in metabolic impairment. The ash content $(\mathrm{g} / 100 \mathrm{~g})$ of cucumber parts; peel, pulp and seed ranged (11.6 - 7.85). The highest level recorded was in pulp (11.6) and the lowest value was in peel (7.85). This ash content was lower in the peel compared to other parts of the cucumber. The ash content in this work was similar to the values earlier reported for various parts of Cucumis sativus [13].

The moisture content ( $\mathrm{g} / 100 \mathrm{~g}$ ) of cucumber parts: peel, pulp and seed ranged from 12.3 - 21.7. The highest level recorded was in peel (21.7) while the lowest

Table 1. Proximate composition (mg/100 g) and Energy values as contributed by protein, fat and carbohydrate in cucumber peel, pulp and seed.

\begin{tabular}{ccccccccccc}
\hline Parameters & Peel & Pulp & Seed & Mean & SD & CV\% & $\chi^{2}$ & Table & Remark \\
\hline \%Ash & $7.85 \pm 0.13$ & $11.6 \pm 0.02$ & $9.34 \pm 0.62$ & 9.60 & 1.89 & 19.7 & 0.74297 & 5.991 & NS \\
\%MC & $21.7 \pm 0.15$ & $12.9 \pm 0.06$ & $12.3 \pm 0.42$ & 15.6 & 5.26 & 33.7 & 3.54286 & 5.991 & NS \\
\%CP & $26.5 \pm 0.02$ & $15.9 \pm 0.02$ & $24.5 \pm 0.06$ & 22.3 & 5.63 & 25.3 & 2.84484 & 5.991 & NS \\
\%Fat & $1.44 \pm 0.39$ & $0.13 \pm 0.02$ & $0.70 \pm 0.02$ & 0.757 & 0.657 & 86.8 & 1.14035 & 5.991 & NS \\
\%Fibre & $8.86 \pm 0.11$ & $6.77 \pm 0.02$ & $3.00 \pm 0.04$ & 6.21 & 2.97 & 47.8 & 2.84061 & 5.991 & NS \\
\%CHO & $33.7 \pm 0.48$ & $52.7 \pm 0.08$ & $50.1 \pm 0.30$ & 45.5 & 10.3 & 22.6 & 4.66462 & 5.991 & NS \\
Gross Energy (kJ/100 g) & $1077 \pm 23.4$ & $1171 \pm 2.30$ & $1296 \pm 6.60$ & 1181 & 110 & 9.30 & 20.4351 & 5.991 & S \\
\%PEP & $41.8 \pm 0.34$ & $23.1 \pm 0.26$ & $32.2 \pm 0.97$ & 32.4 & 9.35 & 28.9 & 5.4033 & 5.991 & NS \\
\%PEF & $5.1 \pm 14.9$ & $0.42 \pm 0.76$ & $2.06 \pm 0.58$ & 2.53 & 2.37 & 94.0 & 4.46354 & 5.991 & NS \\
\%PEC & $53.2 \pm 8.14$ & $76.5 \pm 1.28$ & $65.8 \pm 5.04$ & 65.2 & 11.7 & 17.9 & 4.17463 & 5.991 & NS \\
\%UEDP & $25 \pm 0.34$ & $13.9 \pm 0.26$ & $19.3 \pm 0.97$ & 19.4 & 5.55 & 28.6 & 3.17629 & 5.991 & NS \\
\hline
\end{tabular}

$\mathrm{PEF}=$ Proportion of total energy due to fat; PEP = Proportion of total energy due to Protein; PEC = proportion of total energy due to carbohydrate; UEDP $=$ utilization energy due to protein, $S=$ significantly different at $(p>0.05, n-1), S D=$ standard deviation of the results from the three parts, $C V=$ coefficient of variation, $\chi^{2}=$ chi-square analysis. 
value was in seed (12.3). The value for moisture content reported was similar to the values earlier reported for various parts of Borassus aethiopium mart (11.3 24.1) g/100 g by Waziri and Akinniyi [14]. The moisture content of the cucumber parts cannot be easily stockpiled for a longer period because it is liable to mould growth, as it has high moisture content [15]. High moisture content of vegetables enhances the growth of microorganisms. Protein contents, of cucumber parts: peel, pulp and seed ranged between 15.9 - $26.5 \mathrm{~g} / 100 \mathrm{~g}$. The highest level obtained was in peel $(26.5 \mathrm{~g} / 100 \mathrm{~g})$ and the lowest value was in pulp $(15.9 \mathrm{~g} / 100 \mathrm{~g})$, the protein content in this research was comparatively lower than the values earlier reported for Cucumis sativus (18.7 - 29.4) g/100 g [13]. The proper recycling of cucumber seed and peel in the present study could lead to many economical protein containing products. The result for the fat content corroborates the general observation that vegetables are low lipid containing foods [16]. The fat content of cucumber parts; peels, pulp and seed ranged from $0.13-1.44 \mathrm{~g} / 100 \mathrm{~g}$, the peel had the highest value $(1.44 \mathrm{~g} / 100 \mathrm{~g})$ and the lowest value was in pulp $(0.13 \mathrm{~g} / 100 \mathrm{~g})$, the value of fat content was comparable to the values earlier reported for various parts of Cucumis sativus (0.08 - 0.98) g/100 g by Waziri and Saleh [13]. In the present study, the fibre content of cucumber parts; peel, pulp and seed ranged from 3.00 - $8.86 \mathrm{~g} / 100 \mathrm{~g}$. the highest level recorded was in pulp ( $8.86 \mathrm{~g} / 100 \mathrm{~g})$ and the lowest value was in seed $(3.00 \mathrm{~g} / 100 \mathrm{~g})$, the fibre content in this research was in agreement with the values earlier reported for various parts of Cucumis sativus $(2.21$ - 11.01) g/100 g [13]. The average crude fibre contents in this research showed the ability of cucumber to maintain internal distension for a normal peristaltic movement of the intestinal tract which is one of the major physiological roles that crude fibre plays in the living system. These results showed the importance of the peel as a source of dietary fibre since food with a fibre content of $6.0 \%$ can be considered high. The carbohydrate content of cucumber parts (peel, pulp and seed) ranged from 33.7 $52.7 \mathrm{~g} / 100 \mathrm{~g}$. the highest level recorded was in pulp (52.7 g/100 g) and the lowest value was in peel $(33.7 \mathrm{~g} / 100 \mathrm{~g})$, the fat content in this work was comparable to the values earlier reported for various parts of Cucumis sativus (38.8 - 72.6) $\mathrm{g} / 100 \mathrm{~g}$ [13].

The energy values $(\mathrm{kJ} / \mathrm{kg})$ of the cucumber parts; peel, pulp and seed ranged from 1077 - 1296. The highest energy level recorded was in seed (1296) and the lowest value was in peel (1077). The various proportions of energy contributions due to fat, protein and carbohydrate (PEF\%, PEP\% and PEC \%) as well as $\mathrm{UEDP} \%$ (utilizable energy due to protein). PEF\% values ranged as follows: raw (0.42 - 5.1), the highest level being $5.1 \%$ in the peel of cucumber, pulp (0.42), and seed $(2,1)$. These values were lower compared with the values reported in Nutrient content of food portions (8.43\%) [17]. PEP\% values ranged as follows: raw (23.1 - 41.8), the highest level being $41.8 \%$ in the peel of cucumber, seed (32.2), and the lowest in Pulp (23.1\%). These values were lower compared with the values reported in Nutrient content of food portions (60.13\%) [17]. PEC\% in 
the samples were as follows: peel (53.2), pulp (76.5) and seed (65.8). The fat contribution of $5.1 \%$ of total energy fell greatly below the $30 \%$ recommended energy from fat particularly for adults [17]. The utilizable energy due to protein (UEDP \%) for the samples (assuming $60 \%$ utilization) ranged from 13.9 - 25.0. These values were higher than the recommended safe level of $8 \%$ for an adult man who requires about $55 \mathrm{~g}$ protein per day with $60 \%$ utilization [18]; this means the protein energy contribution in cucumber parts would be more than enough to prevent protein energy malnutrition (PEM) in an adult consuming whole cucumber as a main source of protein [18]. UEDP \% is relative to the level of proteins in samples, therefore the higher levels of UEDP could be attributed to the averagely high level of protein in the cucumber peel, pulp and seed.

\subsection{Mineral Composition and Safety Index}

Mineral compositions of the samples were shown in Table 2. Minerals are important in human nutrition. It is well known that enzymatic activities as well as electrolytic balance of the body fluid are related to the adequacy of $\mathrm{Na}, \mathrm{K}, \mathrm{Mg}$ and $\mathrm{Zn}$. Potassium is very important in maintaining body fluid volume and osmotic equilibrium, the $\mathrm{pH}$ of the body, regulation of muscles and nerve irritability, control of glucose absorption and enhancement of normal retention of protein during growth [19]. Metal deficiency syndrome like rickets, and calcification of bone is caused by calcium deficiency. Minerals in adequate amount ensure the normal physiological functions, including iron utilization [20]. The present report showed that sodium had the highest concentration in the Cucumber seed $(156 \mathrm{mg} / 100 \mathrm{~g})$ followed by the pulp $(151 \mathrm{mg} / 100 \mathrm{~g})$ and then the peel $(113$ $\mathrm{mg} / 100 \mathrm{~g})$. This implies that the seed had higher Na value than other parts of the cucumber. Sodium regulates fluid balance in the body and helps in the proper functioning of muscles and nerves [21]. The daily value for sodium is $2400 \mathrm{mg}$ for adults and children aged 4 and older. However, there is a need to consider this sample, especially in sodium and potassium restricted diets. This is important since high dietary sodium is connected in cardiovascular and renal disorders [22]. Similarly, sodium is not recommended for people who suffer from or are prone to hypertension. Levels of potassium in the cucumber parts (peel, pulp and seed) were 454,437 and $541 \mathrm{mg} / 100 \mathrm{~g}$ respectively. The seed had the highest value $(541 \mathrm{mg} / 100 \mathrm{~g})$ whereas pulp had the lowest value $(437 \mathrm{mg} / 100 \mathrm{~g})$. The high concentration of potassium in the body was reported to increase iron utilization [23] and beneficial to people taking diuretics to control hypertension and suffer from excessive excretion of potassium through the body fluid [24]. Potassium is available in several foods like fruits, dairy products and vegetables and its recommended daily intake value stands at $3500 \mathrm{mg}$. The concentrations of calcium were found in the cucumber parts (Peel, Pulp and Seed) to be 168, 139, 177 $\mathrm{mg} / 100 \mathrm{~g}$ respectively, the pulp that is mostly consumed was observed to have the least calcium concentration when compared to the seed and peel. Calcium is a constituent of bones and helps in contraction process in the body, blood clotting and the nerves to convey messages. When the calcium supply to the body 
Table 2. Mineral composition and mineral ratio of cucumber peel, pulp and seed (mg/100 g).

\begin{tabular}{|c|c|c|c|c|c|c|c|c|c|}
\hline Minerals & Peel & Pulp & Seed & Mean & SD & $\mathrm{CV} \%$ & $x^{2}$ & Table & Remark \\
\hline Sodium (Na) & $113 \pm 0.02$ & $151 \pm 0.01$ & $156 \pm 0.02$ & 140 & 23.5 & 16.8 & 7.90 & 5.991 & S \\
\hline Potassium (K) & $454 \pm 0.01$ & $437 \pm 0.01$ & $541 \pm 0.01$ & 477 & 55.8 & 11.7 & 13.0 & 5.991 & $S$ \\
\hline Magnesium (Mg) & $64.1 \pm 0.01$ & $70.8 \pm 0.01$ & $64.4 \pm 0.01$ & 66.4 & 3.78 & 5.70 & 0.431 & 5.991 & NS \\
\hline Calcium (Ca) & $168 \pm 0.01$ & $139 \pm 0.02$ & $177 \pm 0.01$ & 161 & 19.9 & 12.3 & 4.89 & 5.991 & NS \\
\hline Zinc $(\mathrm{Zn})$ & $2.66 \pm 0.02$ & $5.27 \pm 0.01$ & $5.46 \pm 0.02$ & 4.46 & 1.56 & 35.1 & 1.10 & 5.991 & NS \\
\hline Iron $(\mathrm{Fe})$ & $7.39 \pm 0.02$ & $7.80 \pm 0.01$ & $9.08 \pm 0.02$ & 8.09 & 0.88 & 10.9 & 0.192 & 5.991 & NS \\
\hline Cupper $(\mathrm{Cu})$ & $1.69 \pm 0.01$ & $2.49 \pm 0.02$ & $2.21 \pm 0.01$ & 2.13 & 0.41 & 19.1 & 0.155 & 5.991 & NS \\
\hline Manganese (Mn) & $0.4 \pm 0.01$ & $0.79 \pm 0.01$ & $0.56 \pm 0.01$ & 0.583 & 0.196 & 33.6 & 0.132 & 5.991 & NS \\
\hline Lead $(\mathrm{Pb})$ & $0.82 \pm 0.02$ & $1.31 \pm 0.01$ & $0.94 \pm 0.02$ & 1.023 & 0.255 & 25.0 & 0.127 & 5.991 & NS \\
\hline Cadmium (Cd) & $0.18 \pm 0.02$ & $0.27 \pm 0.01$ & $0.1 \pm 0.01$ & 0.183 & 0.085 & 46.4 & 0.079 & 5.991 & NS \\
\hline Nickel (Ni) & $0.09 \pm 0.01$ & $0.07 \pm 0.01$ & $\mathrm{Nd}$ & 0.053 & 0.047 & 88.6 & 0.084 & 5.991 & NS \\
\hline $\mathrm{Na} / \mathrm{K}$ & $0.25 \pm 2.0$ & $0.36 \pm 1.0$ & $0.29 \pm 2.0$ & 0.30 & 0.06 & 18.6 & 0.021 & 5.991 & NS \\
\hline $\mathrm{K} / \mathrm{Na}$ & $4.02 \pm 0.5$ & $2.89 \pm 1.0$ & $3.47 \pm 0.5$ & 3.46 & 0.57 & 16.3 & 0.185 & 5.991 & NS \\
\hline $\mathrm{Ca} / \mathrm{Mg}$ & $2.62 \pm 1.0$ & $1.96 \pm 2.0$ & $2.75 \pm 1.0$ & 2.44 & 0.42 & 17.3 & 0.147 & 5.991 & NS \\
\hline $\mathrm{K} /(\mathrm{Ca}+\mathrm{Mg})$ & $3.91 \pm 0.5$ & $4.17 \pm 0.33$ & $4.48 \pm 0.5$ & 4.19 & 0.285 & 6.82 & 0.039 & 5.991 & NS \\
\hline
\end{tabular}

Result $=$ Mean \pm SD of duplicate determination, $S=$ significantly different at $(p>0.05, n-1)$, NS = not significantly different at $(p=0.05, n-1), S D=$ standard deviation of the results from the three parts, $\mathrm{CV}=$ coefficient of variation, $\chi^{2}=$ chi-square analysis.

becomes insufficient, the body on its own extracts the needed calcium from the bones. If the body continues to tear down more calcium than it replaces over a period of years the bones will become weak and break easily. Calcium is essential for disease prevention and control and therefore contributes to the medicinal influences of the plant [25]. The copper content of cucumber parts (peel, pulp and seed) were: $1.69,2.49$ and $2.21 \mathrm{mg} / 100 \mathrm{~g}$ respectively. These values were within range of recommended daily allowance of $1.5-3.0 \mathrm{mg}$ per day for adult male and female [21]. The results of the mineral content in this study compared favourably with that of Olatunde and Onisoya [26]. Cucumber can therefore be recommended as good source of copper. Copper helps the body to use iron and sugar properly. It is also necessary for bone growth and nerve function. Deficiency of copper may result in anaemia and osteoporosis (weak bones). Manganese plays a vital role in the formation of connective tissues, bones, nerves, sex hormones, blood clotting factors are present in the cucumber parts (peel, pulp and seed) with the following values: $0.4,0.79,0.56 \mathrm{mg} / 100 \mathrm{~g}$. The pulp contained the highest value of Manganese. Iron has the highest concentration in the cucumber seed $(9.08 \mathrm{mg} / 100 \mathrm{~g})$ compared to pulp and peel. Iron is said to be important element in the diet of pregnant women, nursing mother and infant to prevent anaemia [27]. The levels of zinc in Cucumber parts (peel, pulp and seed) were $2.66,5.27$ and $5.46 \mathrm{mg} / 100 \mathrm{~g}$ respectively, although very low but mayplay a major role in normal body development since zinc is essential element in protein and nucleic acid synthesis [28]. Cucumber seeds showed appreciable high level 
of most of the minerals assessed when compared to the pulp and peel. This implies that the seeds could be a good source of these elements. The presence of lead and cadmium at levels slightly higher than $0.00 \mathrm{mg} / 100 \mathrm{~g}$ in all the samples was an indication of the onset of environmental pollution [29].

Mineral ratios were also depicted in Table $2 . \mathrm{Na} / \mathrm{K}$ plays a very important role in diet as it controls high blood pressure in the body. Studies have shown that lower sodium and higher potassium intake helps to reduce high blood pressure in hypertensive patients [30]. The recommended $\mathrm{Na} / \mathrm{K}$ ratio should be less than one. The $\mathrm{Na} / \mathrm{K}$ value of $0.25,0.36$ and 0.29 was observed in Cucumber parts (peel, pulp and seed). The $\mathrm{K} / \mathrm{Na}$ values of 4.02, 2.89 and 3.47 were also obtained in Cucumber parts (peel, pulp and seed). The present study revealed that regular consumption of Cucumber parts would help to prevent hypertension and may help in lowering of blood pressure in hypertensive patients. This result agreed favourably with the values reported by Aremu et al. [31] on Nigerian underutilized legumes as good sources of diets for lowering blood pressure. The $\mathrm{Ca} / \mathrm{Mg}$ values ranged between 1.96 and 2.75 among the cucumber parts whereas the recommended value is 1.0. Both $\mathrm{Ca}$ and $\mathrm{Mg}$ would need adjustment for good health. The values of milliequivalent ratios $[\mathrm{K} /(\mathrm{Ca}+\mathrm{Mg})]$ were $3.91,4.17$ and 4.48 in the peel, pulp and seed respectively. These values were greater than recommended values of 2.2. This indicates that none of the cucumber parts considered is likely to promote hypomagnesaemia in man [19].

The Mineral Safety Index (MSI) values of the samples were shown in Table 3. The standard MSI for the elements were Fe (6.7), $\mathrm{Na}$ (4.8), $\mathrm{Ca}$ (10), $\mathrm{Zn}$ (33), $\mathrm{Cu}$ (33) and $\mathrm{Mg}$ (15). In this study, the MSI values of Iron in Cucumber parts (peel, pulp and seed) ranged from 3.3 - 4.06, while that of sodium in Cucumber parts (peel, pulp and seed) ranged from 1.08, 1.45 and 1.5 respectively. This implies that the body cannot be overloaded with sodium which usually results in secondary hypertension. The values MSI of calcium in the Cucumber parts peel (1.4), pulp (1.16) and seeds (1.47) where shown in Table 3 clearly shows that calcium content in the analysed parts of the cucumber cannot result in calcium overloading when consumed. Moreover, the MSI calculated values of Zinc, Copper and

Table 3. Mineral safety index of Fe, Na, Ca, $\mathrm{Zn}, \mathrm{Cu}$ and $\mathrm{Mg}$ for the Cucumber parts (Peel, Pulp and Seed) samples.

\begin{tabular}{cccccccccc}
\hline Parameters & \multicolumn{3}{c}{ Peel } & \multicolumn{3}{c}{ Pulp } & \multicolumn{3}{c}{ Seed } \\
\hline & TV & CV & D & TV & CV & D & TV & CV & D \\
\hline Fe & 6.70 & 3.30 & 3.40 & 6.70 & 3.48 & 3.22 & 6.70 & 4.06 & 2.64 \\
$\mathrm{Na}$ & 4.80 & 1.08 & 3.72 & 4.80 & 1.45 & 3.35 & 4.80 & 1.50 & 3.30 \\
$\mathrm{Ca}$ & 10.0 & 1.40 & 8.60 & 10.0 & 1.16 & 8.84 & 10.0 & 1.47 & 8.53 \\
$\mathrm{Zn}$ & 33.0 & 5.85 & 27.2 & 33.0 & 11.6 & 21.4 & 33.0 & 12.0 & 21.0 \\
$\mathrm{Cu}$ & 33.0 & 2.54 & 30.5 & 33.0 & 3.74 & 29.3 & 33.0 & 3.32 & 29.7 \\
$\mathrm{Mg}$ & 15.0 & 2.40 & 12.6 & 15.0 & 2.66 & 12.3 & 15.0 & 2.42 & 12.6 \\
\hline
\end{tabular}

$\mathrm{TV}=$ Table Value; $\mathrm{CV}=$ Calculated Value; $\mathrm{D}=$ Difference. 
Magnesium in all the parts of cucumber studied were significantly below the standards and this implies that consumption of the analysed cucumber parts are safe. In other words, the explanation of the MSI can be understood as follows: if the Recommended Adult Intake (RAI) of $\mathrm{Ca}$ is $1200 \mathrm{mg}$, its Minimum Toxic Dose (MTD) is $12000 \mathrm{mg}$ or 10 times the Recommended Daily Average (RDA) which is equivalent to MSI of Ca. This is applicable to other minerals determined. All Cucumber parts (peel, pulp and seeds) studied gave positive MSI values for all the elements examined, indicating that none of them would constitute mineral overload or become toxic to the Cucumber consumers.

\section{Conclusion}

On the basis of comparative assessment, cucumber peel, pulp and seeds were good sources of protein, fat, energy, essential minerals. The $\mathrm{Na} / \mathrm{K}, \mathrm{Ca} / \mathrm{P},[\mathrm{K} /(\mathrm{Mg}$ $+\mathrm{Ca})]$ ratios and mineral safety index were positive. It is worthy to note that nutrient distributions were in the following trends: crude protein and fat (peel $>$ seed $>$ pulp), fibre (peel $>$ pulp $>$ seed), $\mathrm{CHO}$ (pulp $>$ seed $>$ peel) gross energy ( seed $>$ pulp $>$ peel) and in terms of mineral contributions, $\mathrm{Na}, \mathrm{K}, \mathrm{Ca}, \mathrm{Zn}$ and $\mathrm{Fe}$ were most concentrated in the seed whereas $\mathrm{Mg}, \mathrm{Cu}$ and $\mathrm{Mn}$ were most concentrated in the pulp and the peel had the least concentrations of minerals. Its adequate mineral contents have potentials to meet the nutritional requirements of human health especially minerals needed for blood formation and transportation of oxygen and carbon dioxide between tissues.

\section{Conflicts of Interest}

The authors declare no conflicts of interest regarding the publication of this paper.

\section{References}

[1] Thoa, D.K. (1998) Cucumber Seed Multiplication and Characterization. AVRDC/ARC Training Thailand.

[2] Wehner, T.C. and Guner, N. (2004) Growth Stage, Flowering Pattern, Yield and Harvest Date Prediction of Four Types of Cucumber Tested at 10 Planting Dates. Acta Horticulturae, 637, 223-227. https://doi.org/10.17660/ActaHortic.2004.637.27

[3] Tatlioglu, T. (1997) Cucumber (Cucumis sativus L.). In: Kailov, G. and Bergn, B., Eds., Genetic Improvement of Vegetable Crops, Pergamon Press, Oxford, 197-227. https://doi.org/10.1016/B978-0-08-040826-2.50017-5

[4] Phu, N.T. (1997) Nitrogenand Potassium Effect on Cucumber Yield. AVI 1997 Report, ARC/AVRDC Training Thailand.

[5] Food and Agricultural Organization (FAO) (2000) The Fifth World Food Survey. FAO, Rome.

[6] Werner (2005) The Effect of the Nutrient Concentration in the Propagation of Tomatoes and Cucumber on Rockwool. Acta Horticulturae, 178, 59-65.

[7] Clark, A.M. (2007) Echinodermata of the Seychelles. In: Stodart, D.R., Ed., Biogeography and Ecology of the Seychelles Islands, Monographiae Biologicae, Vol. 55, 
Springer, Berlin, 83-102.

[8] McCoy, A.L., O’Callaghan, Y.C. and O’Brien, N.M. (2001) Protein Hydrolysates from Agricultural Crops-Bioactvitiy and Potential for Functional Food Development. Agriculture, 3, 112-130. https://doi.org/10.3390/agriculture3010112

[9] Pearson, D.H. (1976) Chemical Analysis of Foods. Churchill, London, 335-336.

[10] AOAC (2005) Official Methods of Analysis. 18th Edition, AOAC International, Rockville.

[11] Watts, D.L. (2010) HTMA Mineral Ratios: A Brief Discussion of Their Clinical Importance. Trace Elements Newsletter, 21, 1-3.

[12] Oloyo, R.A. (2001) Fundamentals of Research Methodology for Social and Applied Sciences. ROA Educational Press, Ilaro, 53-200.

[13] Waziri, M. and Saleh, I.A. (2015) Proximate Analysis and Phytochemical Screening of Psidium guajava (Guava) and Cucumis sativus (Cucumber) Grown in Gashua Fadama Area of Yobe State, Nigeria. IRJPAC, 6, 77-83. https://doi.org/10.9734/IRJPAC/2015/13775

[14] Waziri, M. and Akinniyi, J.A. (2011) Proximate Value and Mineral Content of the Shoot of Borassus aethiopum Mart (Giginya). Journal of Chemical Society of Nigeria, 36, 10-14.

[15] Werthera, J., Saengera, M., Hartgea, E.U., Ogadab, T. and Siagib, Z. (2000) Combustion of Agricultural Residues. Progress in Energy and Combustion Science, 26, 1-27. https://doi.org/10.1016/S0360-1285(99)00005-2

[16] Sotelo, A., Semei, L.G. and Francisco, B.P. (2007) Content of Nutritional and Antinutritionals in Edible Flowers of Wild Plant in Mexico. Plant Foods for Human Nutrition, 62, 132-138.

[17] Davies, J. and Dickerson, J. (1991) Nutrient Content of Food Portions. Royal Society of Chemistry, Cambridge, 1-53.

[18] FAO/WHO/UNU (1985) Energy and Protein Requirements. WHO Technical Report Series 724, WHO, Geneva.

[19] National Research Council (NRC) (1989) Food and Nutrition Board Recommended Dietary Allowances. 10th Edition, National Academy Press, Washington DC, 82.

[20] Adeyeye, E.I. (2000) Bio-Concentration of Macro and Trace Minerals in Four Prawns Living in Lagos Lagoon. Pakistan Journal of Scientific and Industrial Research, 43, 367-373.

[21] Jacob, A.G., Etong, D.I. and Tijjani, A. (2015) Proximate, Mineral and Anti-Nutritional Compositions of Melon (Citrullus lanatus) Seeds. British Journal of Research, 2, 142-151.

[22] Aletor, V.A. and Adeogun, O.A. (1995) Nutritional and Anti-Nutrient Components of Some Tropical Leafy Vegetables. Food Chemistry, 53, 375-379. https://doi.org/10.1016/0308-8146(95)99830-S

[23] Adeyeye, E.I. (2002) Determination of Chemical Composition of the Nutrionally Valuable Parts of Male and Female Common West African Fresh Water Crab ( $\mathrm{Su}$ dananoutes africanus). International Journal of Food Sciences and Nutrition, 53, 189-196. https://doi.org/10.1080/09637480220132805

[24] Arinanthan, V., Mohan, V.R. and Britto, A.J. (2003) Chemical Composition of Certain Tribal Pulses in South India. International Journal of Food Sciences and Nutrition, 3, 103-107. https://doi.org/10.1080/09637480120092026

[25] Aliyu, A.B., Musa, A.M. and Oshaniyi, J.A. (2008) Phytochemical Analysis and 
Mineral Composition Analysis of Some Medicinal Plants of Northern Nigeria. Nigerian Journal of Pharmaceutical Sciences, 7, 119.

[26] Olatunde, S.E. and Onisoya, M.O. (2017) Assessment of Heavy Metal Concentration in Pawpaw (Carica papaya Linn) around Automobile Workshops in Port-Harcourt Metropolis Rivers State Nigeria. Journal of Health and Pollution, 7, 48-61. https://doi.org/10.5696/2156-9614-7.14.48

[27] Oluyemi, E.A., Akinlua, A.A., Adenuga, A.A. and Adebayo, M.B. (2006) Mineral Contents of Some Commonly Consumed Nigeria Foods. Science Focus, 11, 153-157.

[28] Abitogun, A.S., Ashogbon, A.O. and Borokin, F.B. (2010) Nutritional and Chemical Compositions of Ripe and Unripe Vitex glandifolia. Journal of Research in National Development, 8, 1-5.

[29] Ubom, G.A. (1991) The Goitre-Soil-Water-Diet Relationship: Case Study in Plateau State Nigeria. Science of the Total Environment, 107, 1-11. https://doi.org/10.1016/0048-9697(91)90246-B

[30] Daffodil, E.D., Tresina, P.S. and Mohan, V.R. (2016) Nutritional and Antinutritional Assessment of Mucuna pruriens (L) DC var. Utilid (Wall ex. Wight). Bak. Ex Burck and Mucuna deeringiana (Bort) Merril: An Underutilized Tribal Pulse. International Food Research Journal, 23, 1501-1513. https://doi.org/10.1016/B978-0-12-384947-2.00036-2

[31] Aremu, M.O., Olaofe, O. and Akintayo, T.E. (2006) A Comparative Study on the Chemical and Amino Acid Composition of Some Nigerian Underutilized Legumes Flours. Pakistan Journal of Nutrition, 7, 381-384.

https://doi.org/10.3923/pjn.2006.34.38 